\title{
AZ AMERIKAI TRANSZNACIONÁLIS VÁLLALATOK LOKALIZÁCIÓJA 1983 ÉS 2007 KÖZÖTT
}

\author{
(Localization of U.S. Transnational Corporations \\ between 1983 and 2007)
}

\author{
CSIKI ANITA
}

\begin{abstract}
Kulcsszavak:
amerikai transznacionális vállalat terjeszkedés lokáció értékesítés

A transznacionális társaságok (TNC) kétségtelenül a világgazdaság leginkább meghatározó szereplőivé váltak. E vállalatok óriási jelentöséggel rendelkeznek a technológia, a termelés, a tökebefektetések és a kereskedelem terén is. A tanulmányban az értékesítési mutatók segítségével az amerikai TNC-k külpiaci terjeszkedését mutatjuk be. Ehhez áttekintjük, hogy az amerikai vállalatok hálózata miként szervezödik, illetve milyen átrendezödési folyamatok zajlottak le az utóbbi években.
\end{abstract}

A globalizáció új tendenciákat eredményez a gazdaság térfolyamataiban is: új ipari terek születnek, új növekedési pólusok jönnek létre, egy olyan új globális térgazdaság formálódik, amelyet a gazdasági tevékenységek nagyfokú egységesülési folyamata jellemez. Dicken (2003) az így kialakuló új világgazdaságot „,new geo-economy”-nak nevezi. Ebben az új gazdasági térben átértékelődik az egyes területi szintek (1) globális szint, 2) szupranacionális szint, 3) nemzeti szint, 4) szubnacionális szint) szerepe. A globális gazdaságot meghatározó öt folyamat (a TNC-k tevékenysége, technológiai fejlődés, nemzetközi integrációk létrejötte, új globális pénzügyi rendszerek kialakulása, termékek és szolgáltatások előállítása) mindegyike hatást gyakorol ezekre a térségi szintekre. A tanulmány témáját tekintve felvetődik a kérdés, hogy vajon napjainkban szupranacionális és globális szinten milyen tényezők határozzák meg a vállalatok lokalizációs döntéseit, és ennek következtében mi jellemző a TNC-k térszerveződésére? Az éleződő globális versenyben a vállalati üzletpolitika fontos eszköze a lokalizációs stratégia. Bernek $(2002,166)$ szerint e stratégia legfontosabb célja, „hogy kiválassza az adott vállalat müködéséhez legkedvezőbb stratégiai földrajzi helyet”. A TNC-k lokalizációs stratégiája határozza meg a vállalat beruházásainak, vállalati egységeinek földrajzi megoszlását, azaz a telephelyhálózat alakulását. A cél természetesen a „globális optimalizáció”, vagy másképpen fogalmazva az „abszolút költségelőny”, amelyre Bernek $(2002$, 162) szerint minden világgazdasági és nemzetgazdasági tendencia visszavezethetö.

A transznacionális vállalatok lokalizációs döntései sok makro- és mikrogazdasági, valamint társadalmi és politikai tényező elemzésén alapulnak. A célpiac mérete és a termelési költségekben mutatkozó eltérések jelentik a legalapvetőbb szempontokat. 1999-ben a beruházási célterület megválasztása során a legfontosabb tizenkét szempont fontossági sorrendje a következők szerint alakult (Simai-Gál 2000): 1) piac 
bövülése, 2) piac nagysága, 3) profitkilátások, 4) politikai és társadalmi biztonság, 5) jogi szabályozás környezete, 6) munkaerö minösége, 7) üzleti infrastruktúra minösége és az üzleti környezet, 8) emberi és pénzügyi eröforrásokhoz való hozzájutás, 9) bérköltségek, 10) $K+F$ források és képességek, 11) állami kereskedelem-politika jellege, 12) nyersanyagforrások közelsége és hozzáférhetősége. Az egyes tényezők fontossága azonban országonként és iparáganként is eltérhet. A japán transznacionális vállalatok esetében például a nyersanyaghoz való hozzáférés biztosítása fontosabb lesz, mint általában a transznacionális vállalatoknál. Az elektronikai cégeknél pedig az olcsó munkaerő jelentősége kap a többi iparághoz képest nagyobb szerepet.

\section{Az amerikai vállalatok terjeszkedése és lokalizálódása az értékesitési mutatók alapján}

A továbbiakban az amerikai TNC-k külföldi leányvállalatainak tevékenységét időbeni aspektusból, az értékesítési (kibocsátási) adatokra alapozva vizsgáljuk. Az amerikai vállalatok eladási adatai az Amerikai Gazdaságelemző Hivataltól ( „Bureau of Economic Analysis” - BEA) származnak. A vizsgálat a többségi amerikai tulajdonban lévő külföldi leányvállalatokra korlátozódik, mivel az értékesítési adatok közlése e leányvállalatok esetében a legrészletesebb. Mivel azonban az amerikai leányvállalatok jelentős részét a többségi amerikai tulajdonban lévő leányvállalatok teszik ki (2007-ben a leányvállalatok 94\%-a volt többségi amerikai tulajdonban), megítélésünk szerint megengedhető az ilyen jellegü szűkítés.

A tanulmány céljául - az amerikai vállalatok terjeszkedésével, külpiaci lokációjával kapcsolatosan - az alábbi kutatási kérdések vizsgálatát tüztük ki:

1) Az amerikai TNC-k nemzetköziesedettsége fokozódott-e a vizsgált időszak (1983-2007) folyamán, azaz idővel az amerikai vállalatokra erőteljesebb aktivitás jellemző-e a külpiacokon, mint az USA belső piacán?

2) A változó világgazdasági körülmények hatására a leányvállalatok területileg kevésbé koncentráltan szerveződnek-e, vagyis kimutatható-e, hogy az amerikai vállalatok földrajzi hálózata 1983 és 2007 között egyenletesebbé vált?

3) Az amerikai vállalatok szemszögéböl nézve idővel érdemben átértékelödött-e az egyes nagytérségek és államok jelentősége?

\section{Az amerikai vállalatok növekvö nemzetköziesedettsége}

Első kérdésünk arra vonatkozott, hogy az amerikai TNC-k nemzetköziesedettsége fokozódott-e az 1983 és 2007 közötti időszakban. Hogy erre a kérdésre választ adhassunk, az amerikai transznacionális vállatok külpiaci tevékenységét az összvállalati szinten végzett tevékenységgel vetettük össze három mutatóra (vagyon, értékesítés, foglalkoztatottság) alapozva. Ez a gyakorlatban azt jelenti, hogy a külföldön működő 
leányvállalatok összes vagyonát az összesített vállalati vagyonhoz, a leányvállatok eladási adatait az összesített vállalati eladáshoz, a külföldi foglalkoztatottak számát az összvállalati foglalkoztatottak számához viszonyítottuk. Az így kiszámított három nemzetköziesedettséget mérö indexből (Vagyon index=AI; Értékesítési index=SI; Foglalkoztatottsági index=EI) egyszerü átlagolással számítottuk ki az UNCTAD által képzett TNI-t (lásd pl. UNCTAD 1995).

A nemzetköziesedettséget mérő indexek alakulását az 1. ábra mutatja: valamennyi index esetében azt láthatjuk, hogy az amerikai vállalatok 1983 és 2007 között fokozták külpiaci aktivitásukat. Ma már azt is kimondhatjuk, hogy az amerikai vállalatok tevékenységük 1/3-át a külső piacokon végzik.

A nemzetköziesedettséget mérő komplex mutatószám (TNI) értéke 1983 és 2007 között 20\%-ról 36\%-ra emelkedett. Az eladások nemzetköziesedettségének indexe (SI) amerikai viszonylatban mindig is a legmagasabb volt, hiszen a végső cél a termékek minél szélesebb körben történő értékesítése (már 1983-ban 23\% volt e mutató értéke, és 2007-ben elérte a 35\%-ot). Ám, ahogy a világgazdaság egyre inkább globalizálódott, úgy vált az amerikai vállalatok egyéb tevékenysége is egyre növekvő mértékben nemzetköziesedettebbé (1. ábra).

\section{1. ÁBRA}

Az amerikai vállalatok növekvö nemzetköziesedettsége 1983 és 2007 között

(The Increasing Transnationality of the U.S. Corporations, 1983-2007)

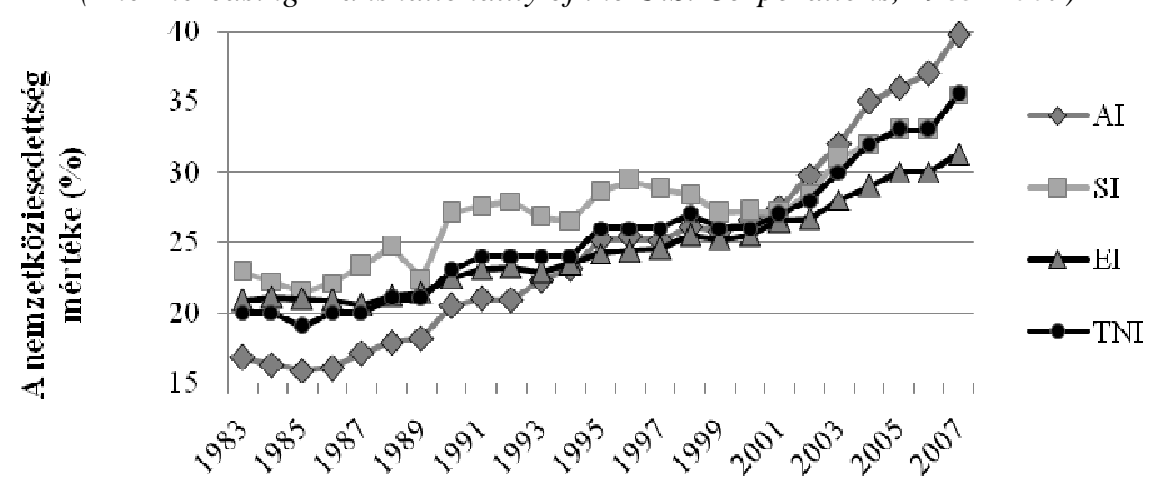

Forrás: http://www.bea.gov alapján saját számítás és szerkesztés.

\section{Az amerikai vállalatok térszervezödése}

A nemzetköziesedettség vizsgálata mellett kérdés volt számunkra az is, hogy a változó világgazdasági körülmények hatására a leányvállalatok területileg kevésbé koncentráltan szerveződnek-e, illetve, hogy idővel átértékelődött-e az egyes nagytérségek és államok jelentősége. E kérdések megválaszolásához áttekintettük, hogy az amerikai leányvállalatok hálózata a földrajzi térben miként szerveződik, az elmúlt években milyen területi átrendeződési folyamatok zajlottak, mely térségek, 
országok szerepe erősödött, illetve relatíve mely országok, országcsoportok jelentősége mérséklődött. Vizsgáltuk az egyes térségeken belüli térszerveződést is, melynek segítségével az egyes térségeken belül zajló folyamatokról kaphatunk áttekintést. Mindezen vizsgálatokhoz részben megoszlási viszonyszámokat számoltunk, de koncentrációs vizsgálatokat (Herfindhal-Hirschman index [HHI], a legnagyobb részesedésü államok együttes részesedését jellemző Koncentrációs-ráta) is végeztünk. (A HHI és a súlypont számításának módszertanát lásd Nemes Nagy [1998] „A tér a társadalomkutatásban” c. müvében.)

A továbbiakban a kutatási eredményeket ismertetjük. A vizsgált időszak során, nagytérségi szinten, jelentős mértékü területi átrendeződés nem volt kimutatható (1. táblázat).

1. TÁBLÁZAT

A föbb térségek részesedése az amerikai leányvállalatok összesített értékesitéséböl (The Share of the Main Regions of the U.S. Affiliates' Sale)

\begin{tabular}{lccccc}
\hline \multicolumn{1}{c}{ Térségek } & $1983-$ & $1989-$ & $1995-$ & $2001-$ & $1999-$ \\
& 1988 & 1994 & 2000 & 2007 & 2007 \\
\hline Kanada & 17,4 & 14,5 & 12,6 & 12,6 & 12,7 \\
Nyugat-Európa & 53,1 & 56,9 & 53,8 & 50,2 & 50,9 \\
Közép-, Kelet-és Délkelet- & 0,1 & 0,2 & 1,0 & 2,0 & 1,2 \\
Európa & 5,1 & 4,3 & 5,3 & 4,6 & 4,7 \\
Dél-Amerika & 2,0 & 2,6 & 3,5 & 4,2 & 4,2 \\
Közép-Amerika & 3,4 & 2,0 & 1,8 & 2,7 & 2,6 \\
Bermuda és a Karib-térség & 1,7 & 0,9 & 0,8 & 1,0 & 1,0 \\
Közel-Kelet & 2,6 & 1,1 & 1,1 & 1,6 & 1,5 \\
Afrika & 3,8 & 3,4 & 3,0 & 2,8 & 2,8 \\
Ausztrália és Új-Zéland & 4,5 & 5,9 & 5,9 & 5,3 & 5,4 \\
Japán & 3,3 & 5,2 & 7,3 & 7,8 & 7,7 \\
Fejlett délkelet-ázsiai álla- & & & & & \\
mok & & 2,2 & 2,5 & 2,7 & 2,6 \\
$\begin{array}{l}\text { Felttörekvő délkelet-ázsiai } \\
\text { államok }\end{array}$ & 2,3 & & & & \\
Kína, India és az egyéb ázsiai & 0,2 & 0,2 & 1,0 & 2,5 & 2,3 \\
államok & & & & & \\
\hline
\end{tabular}

Forrás: http://www.bea.gov. (térfelosztás - 1. térkép) alapján saját számítás.

Afrika és a Közel-Kelet továbbra sem játszik fontos szerepet az amerikai vállalatok nemzetközi hálózatában. A teljes időszakot figyelembe véve a legnagyobb mértékben a közép-, kelet- és délkelet-európai térség, valamint Kína, India és az egyéb ázsiai államok, a fejlett délkelet-ázsiai államok és Közép-Amerika részesedése növekedett. Dél-Amerikát és Japánt stabilan 5-5\% körüli részesedés jellemzi. A Karib-térség részesedése viszont a kilencvenes évek második feléig még csökkent, azóta viszont kismértékü növekedés mutatható ki. A legnagyobb mértékü pozícióvesztést Kanada szenvedte el, de az ország még így is valamivel több, mind egytized arányban részesedik a leányvállalatok összesített értékesítéséből. Bár valamelyest csökkent Nyugat-Európa részesedése is, ám a térség továbbra is $50 \%$ körüli része- 
sedéssel jellemezhető, ami alapján kijelenthető, hogy az amerikai vállalatokra az Európa-központú lokalizációs stratégia továbbra is jellemzö (2. ábra).

\section{2. ÁBRA}

A nagytérségek földrajzi megoszlása

(The Geographic Distribution of the Regions)

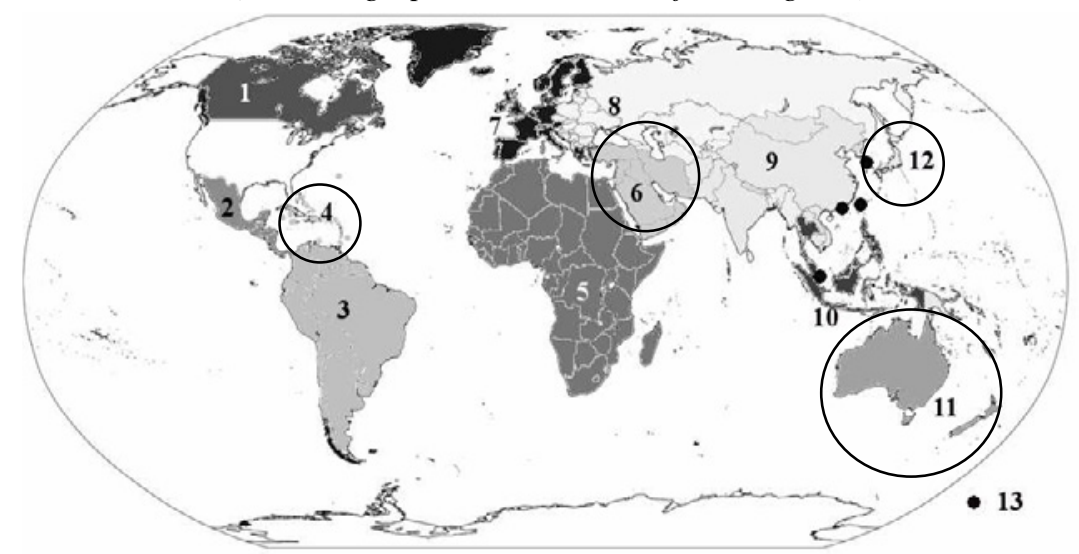

Jelmagyarázat: 1) Kanada, 2) Közép-Amerika, 3) Dél-Amerika, 4) Bermuda és a Karib-térség, 5) Afrika, 6) Közel-Kelet, 7) Nyugat-Európa, 8) Közép-, Kelet- és Délkelet-Európa, 9) Kína, India és az egyéb ázsiai államok, 10) feltörekvő délkelet-ázsiai államok, 11) Ausztrália és Új-

Zéland, 12) Japán, 13) fejlett délkelet-ázsiai államok.

Forrás: Saját szerkesztés.

A BEA adatai azt mutatják, hogy a teljes időszakot figyelembe véve sem következett be számottevő területi átrendeződés, bár néhány ország esetében a változások jelentősek voltak. A napjainkban magas részesedéssel rendelkező államok közül 1983 és 2007 között a legnagyobb arányú növekedést az ír (1\%-ról 5\%-ra), a szingapúri (2\%-ról 5\%-ra), a mexikói (1\%-ról 3-4\%-ra) és a kínai (0\%-ról megközelítőleg 3\%-ra) leányvállalatok érték el. Mellettük néhány korábban periférikus helyzetü, de a kilencvenes évek elejétől felértékelődő piacon (India, Magyarország, Lengyelország, Cseh Köztársaság, Oroszország, Kazahsztán, Azerbajdzsán) is jelentős arányban növekedtek az eladási adatok. A legnagyobb mértékü pozícióvesztést pedig egyértelmüen Kanada szenvedte el (1983 és 2007 között az ország részesedése $17 \%$-ról 11\%-ra esett vissza).

A vizsgálatok során igyekeztük feltárni azt is, hogy a nyolcvanas és a kilencvenes években, illetve az ezredfordulót követő időszakban milyen folyamatok voltak jellemzőek, illetve milyen különbségek mutathatók ki e három időszakot tekintve (2. táblázat). 
2. TÁBLÁZAT

Az egyes országok részesedése a leányvállalatok összesitett értékesitéséböl (The Share of the Main Countries of Affiliates' Total Sale)

\begin{tabular}{|c|c|}
\hline \multicolumn{2}{|r|}{ 1983-1989 ÁTLAGA } \\
\hline magas és növekvő részesedés: & alacsony, de növekvő részesedés: \\
\hline $\begin{array}{l}\text { Franciaország, Németor- } \\
\text { szág, Japán, Olaszország, } \\
\text { Hollandia, Svájc, Egyesüilt } \\
\text { Királyság }\end{array}$ & $\begin{array}{l}\text { Ausztria, Finnország, Írország, Luxemburg, Spanyolor- } \\
\text { szág, Portugália, Törökország, Costa Rica, Honduras, } \\
\text { Mexikó, Barbados, Dominikai Köztársaság, Izrael, } \\
\text { Hongkong, Dél-Korea, Új-Zéland, Tajvan, Thaiföld }\end{array}$ \\
\hline stabilan magas részesedés: & stabilan alacsony részesedés: \\
\hline $\begin{array}{l}\text { Kanada, Brazília, Belgium, } \\
\text { Ausztrália }\end{array}$ & Görögország, Svédország, Chile, Venezuela, Egyiptom \\
\hline magas, de csökkenő részesedés: & alacsony és csökkenő részesedés: \\
\hline Svájc & $\begin{array}{l}\text { Dánia, Norvégia, Argentína, Kolumbia, Ecuador, Peru, } \\
\text { Panama, Bahama-szigetek, Bermuda, brit fennhatóság alatt } \\
\text { álló karibi szigetek, Egyiptom, Nigéria, Dél-afrikai Köztár- } \\
\text { saság, Szaúd-Arábia, Egyesült Arab Emírségek, India, Indo- } \\
\text { nézia, Malajzia, Fülöp-szigetek, Szingapúr, Nigéria }\end{array}$ \\
\hline \multicolumn{2}{|r|}{ 1990-1999 ÁTLAGA } \\
\hline$\frac{\text { magas és növekvő részese- }}{\text { dés: }}$ & $\begin{array}{l}\text { Írország, Luxemburg, Portugália, Svédország, Törökország, } \\
\frac{\text { alacsony, de növekvo részesedés: }}{}\end{array}$ \\
\hline $\begin{array}{l}\text { Hollandia, Hongkong } \\
\text { Mexikó, Szingapúr }\end{array}$ & $\begin{array}{l}\text { Argentína, Chile, Peru, Venezuela, brit fennhatóság alatt } \\
\text { álló karibi szigetek, Dél-afrikai Köztársaság, Izrael, Szaúd- } \\
\text { Arábia, Kína, India, Dél-Korea, Új-Zéland, Malajzia, Fülöp- } \\
\text { szigetek, Dominikai Köztársaság, Tajvan, Thaiföld, Cseh } \\
\text { Köztársaság, Magyarország, Lengyelország, Oroszország }\end{array}$ \\
\hline stabilan magas részesedés: & stabilan alacsony részesedés: \\
\hline Egyesült Királyság, Japán & $\begin{array}{l}\text { Ausztria, Finnország, Görögország, Dánia, Spanyo- } \\
\text { lország, Ecuador, Barbados }\end{array}$ \\
\hline magas, de csökkenő részesedés: & alacsony és csökkenő részesedés: \\
\hline $\begin{array}{l}\text { Kanada, Franciaország, Né- } \\
\text { metország, Belgium, Olaszor- } \\
\text { szág, Svájc, Brazilia, Ausztrália }\end{array}$ & $\begin{array}{l}\text { Norvégia, Columbia, Costa Rica, Honduras, Panama, } \\
\text { Bahama-szigetek, Bermuda, Egyesült Arab Emírségek, } \\
\text { Indonézia, Egyiptom }\end{array}$ \\
\hline \multicolumn{2}{|r|}{ 2000-2007 ÁTLAGA } \\
\hline magas és növekvő részesedés: & alacsony, de növekvő részesedés: \\
\hline $\begin{array}{l}\text { Szingapúr, Svájc, Írország, } \\
\text { Brazília, Ausztrália }\end{array}$ & $\begin{array}{l}\text { Cseh Köztársaság, Görögország, Magyarország, Luxem- } \\
\text { burg, Hollandia, Lengyelország, Oroszország, Törökország, } \\
\text { Ecuador, Peru, Costa Rica, Honduras, Bermuda, brit fenn- } \\
\text { hatóság alatt álló karibi szigetek, Nigéria, Egyesült Arab } \\
\text { Emírségek, Kína, India, Indonézia, Dél-Korea, Thaiföld }\end{array}$ \\
\hline stabilan magas részesedés: & stabilan alacsony részesedés: \\
\hline $\begin{array}{l}\text { Franciaország, } \quad \text { Belgium, } \\
\text { Olaszország, Spanyolország }\end{array}$ & $\begin{array}{l}\text { Ausztria, Dánia, Finnország, Chile, Kolumbia, Venezuela, } \\
\text { Barbados, Egyiptom, Dél-afrikai Köztársaság, Izrael, Malajzia }\end{array}$ \\
\hline magas, de csökkenő részesedés: & alacsony és csökkenő részesedés: \\
\hline $\begin{array}{l}\text { Kanada, Japán, Egyesült } \\
\text { Királyság, } \quad \text { Németország, } \\
\text { Hollandia, Hongkong, Mexikó }\end{array}$ & $\begin{array}{l}\text { Portugália, Svédország, Argentína, Panama, Dominikai } \\
\text { Köztársaság, Szaúd-Arábia, Új-Zéland, Fülöp-szigetek, } \\
\text { Tajvan }\end{array}$ \\
\hline
\end{tabular}

Magas részesedés: $2 \%$ feletti részesedés; Növekvő vagy csökkenő részesedés: a kezdő év részesedéséhez viszonyítva min. 10\%-os változás következett be; Vastag betűvel kiemelt országok: kiemelkedően magas (min. 4\%-os) részesedéssel rendelkeznek.

Forrás: http://www.bea.gov alapján saját számítás. 
A 2. táblázatból látszik, hogy a nyolcvanas években Brazília kivételével csak fejlett államok értek el magasabb, legalább 2\%-os részesedést. Mivel akkoriban a fejlett államok többségét növekvő részesedés jellemezte, tovább erősödött ezen államok pozíciója. A legnagyobb részesedésü fejlett államok közül csak Svájc részesedése csökkent, és csak Kanada, Belgium és Ausztrália részesedése nem változott számottevően, miközben a már amúgy is magas részesedésü Franciaország, Németország, Japán, Olaszország, Hollandia, Svájc és az Egyesült Királyság erősítette pozícióját. A fejlődő térségekben csak kevés olyan ország volt, amelyek relatív pozíciója számottevően erősödött volna. Azok a fejlődő államok, amelyeknél részesedésnövekedés volt mérhető, jellemzően a közép-amerikai országok (Costa Rica, Honduras, Dominikai Köztársaság, Mexikó) és az újonnan iparosodó délkelet-ázsiai államok (Tajvan, Dél-Korea, Thaiföld) közül kerültek ki.

A kilencvenes évekre több változás is történt: A magas részesedésű államok soraiba Szingapúr, Hongkong és Mexikó is bekerült; ezen államok a kilencvenes években tovább növelték részesedésüket. A magas részesedésü fejlett európai államok pozíciója - a növekvő részesedésű Hollandia és a stabilan magas részesedésü Egyesült Királyság kivételével - meggyengült. A nyolcvanas évekhez képest ekkor már kevesebb fejlödő állam volt jellemezhető csökkenő részesedéssel. Ebben az időszakban új célterületek is megjelentek: a vállalatok aktivitása nőtt pl. Kína, India és Közép-, Kelet- és Délkelet-Európa piacain is.

Az ezredfordulót követő időszakban a növekvő részesedésü Svájc ismét felértékelődött az amerikai TNC-k számára. Svájc mellett csak Szingapúrt jellemezte ebben az időszakban kiemelkedően magas (minimum 4\%-os) és növekvő részesedés. További számottevő változás a kilencvenes évekhez képest, hogy Spanyolország is bekerült a magas részesedésű államok közé, miközben a magas részesedésű Franciaország, Olaszország és Belgium kikerült a csökkenő részesedésű államok köréből. Ekkor az alacsonyabb jövedelmü feltörekvő gazdaságok együttes pozíciója már csak kismértékben erősödött tovább. Önmagához viszonyítva a legnagyobb mértékü növekedéssel Kína, illetve néhány - elsődlegesen nyersanyag-orientált befektetéseket vonzó, szénhidrogénekben gazdag - szovjet utódállam (Oroszország, a közép-ázsiai államok) és afrikai ország (Egyenlítői Guinea, Angola) jellemezhető. Mexikó pozíciója eközben gyengült, bár a közép-amerikai állam továbbra is magas részesedéssel rendelkezik.

A vizsgált időszak folyamán - a fent ismertetett folyamatok hatására - az amerikai vállalatok kibocsátási adatok alapján mért területi koncentrációja is változott. A világszinten mért területi koncentráció a nyolcvanas évek végéig erősödött, majd azt követően csökkenés volt tapasztalható. A területi koncentráció számottevően a kilencvenes években mérséklődött, amikor is a feltörekvő piacokon jelentősen növekedni kezdett az amerikai vállatok aktivitása. Mivel az ezredfordulót követő időszakban a termelőterületek köre számottevően nem bővült, jelentősen nem mérséklődött tovább a területi koncentráció sem.

A területi koncentráció csökkenése mind a legnagyobb részesedésü államok együttes részesedését jellemző Koncentrációs-rátával, mind a Herfindhal-Hirschman-Index 
(HHI) alapján (3. ábra) kimutatható. 1983 és 1990 között az 5 legmagasabb értékesítési adatokat elérő ország együttes részesedése 52\%-ról 55\%-ra, a 10 legnagyobb részesedésủ országé pedig 71\%-ról 73\%-ra növekedett. 2007-re azonban az 5 legfontosabb állam összesített részesedése 41\%-ra, a 10 legmagasabb részesedésủ államé 62\%-ra esett vissza. A világ egészére vonatkozó HHI alakulására - akár országos, akár nagytérségi adatokkal mérjük is (3. ábra) - hasonló tendenciák jellemzőek, mint a Koncentrációs-ráta változására, azaz a nyolcvanas években még növekedés jellemezte az index értékét, majd azt követően csökkenés volt kimutatható.

\section{3. ÁBRA}

A HHI változása 1983 és 2007 között

(The Changes of the HHI between 1983 and 2007)

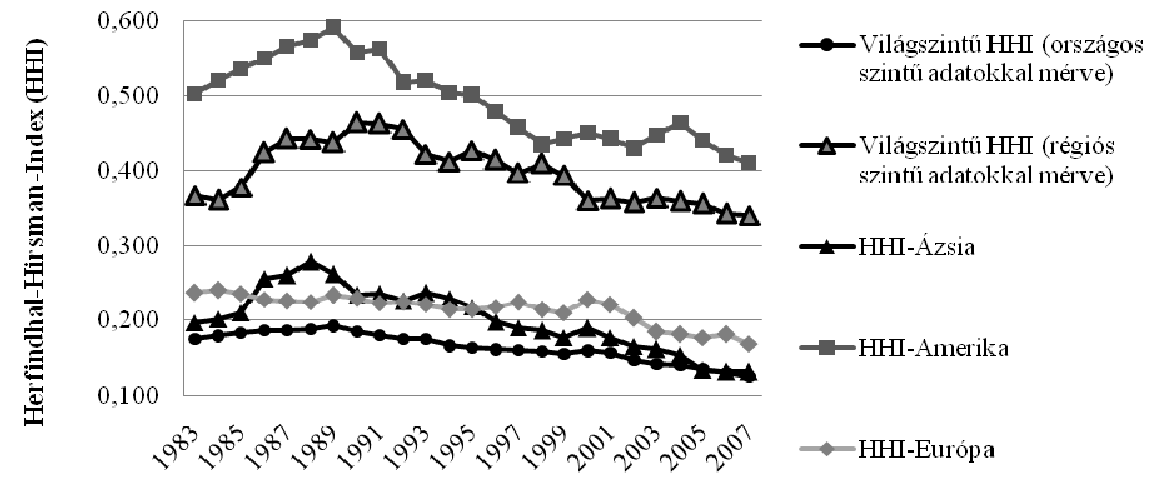

Forrás: http://www.bea.gov alapján saját számítás és szerkesztés.

A továbbiakban azt tekintjük át, hogy a nagytérségek esetében milyen területi átrendeződési folyamatok történtek. A kutatások igazolták, hogy a transzatlanti kapcsolatok továbbra is kiemelt jelentőségüek, hiszen a beruházások fö célterülete mindvégig Európa, azon belül is Nyugat-Európa volt. A nyugat-európai térség legfőbb vonzereje között ott van az egységes és nagy piac, a fejlett gazdaság, az üzleti és gazdasági élet nagyfokú koncentrációja, a képzett munkaerö, a híres egyetemek és kutatóintézetek nagy száma.

Az országos szintủ adatok azt mutatják, hogy a térségen belül a leányvállalatok hálózatára erőteljes területi koncentráció jellemző: a legfontosabb befektetési célterületként számba jövő Egyesült Királyság továbbra is igen magas részesedéssel rendelkezik (a nyugat-európai eladások negyedét bonyolítják le az ott müködő leányvállalatok). Az ország Németországgal együtt a $\mathrm{K}+\mathrm{F}$ tevékenységek legfontosabb célterülete: 2007-ben a külpiaci $\mathrm{K}+\mathrm{F}$ kiadások harmada e két ország leányvállalataihoz volt köthető (Barefoot-Mataloni Jr. 2007, 78). Az Egyesült Királyság kiemelt helyzetét egyrészt az magyarázza, hogy nyelvi és kulturális viszonyait, valamint jogrendszerét tekintve (és földrajzilag is) is igen közel áll az USA-hoz. Emellett fontos tényező az is, hogy London, mint a világ vezető pénzügyi központjainak egyike, igen kedvezö üzleti környezetként szolgál a nemzetközi vállalatok számára. 
Az Egyesült Királyság mellett a Benelux államok (elsősorban Hollandia), Németország, Franciaország, Svájc és Írország számít kiemelkedő befektetési célterületnek (ezen államok együttesen a térség összesített eladásainak 40\%-át bonyolítják le). A nyugat-európai eladásokból való részesedés időbeni változását tekintve Írország szerepének látványos felértékelődése a legszembetűnőbb.

A Benelux államok jelentősége a térség méretéhez képest felülértékeltnek tünhet. $\mathrm{Az}$ amerikai vállalatok gyakran a Benelux államok valamelyikébe telepítik európai regionális központjukat, amit ezen államok nagyrészt kedvező földrajzi helyzetüknek (a „Benelux államokat „Európa kapujának” is nevezik) és közlekedés-földrajzi adottságuknak köszönhetnek (Probáld 2007a, 56). A befektetők számára a Benelux államokban Hollandia kínálja a legkedvezőbb befektetési környezetet. Az ország által kínált előnyök között élen áll a marketing, a kereskedelmi és az egyéb üzleti szolgáltatások magas színvonala, az európai irányító- és elosztó központi funkció és a fejlett gépipar, különösen az orvostechnika, az IT és az elektronika (http://orszaginfo.itdhungary.com). De a kedvező adórendszer is, - melynek számos egyedi sajátossága is van - azt a célt szolgálja, hogy minél több befektető, illetve külföldi vállalat telepedjen meg Hollandiában. Hollandia vonzerejét tovább növeli, hogy a vállalatalapításra uniós összehasonlításban is viszonylag egyszerü és rugalmas szabályok vonatkoznak (http://orszaginfo.itdhungary.com).

Németország a világ harmadik gazdasági hatalma és Európa legnagyobb piaca (Szegedi 2007a, 162), így az amerikai TNC-k számára is fontos a közvetlen piaci jelenlét. A német iparon belül kiemelkedő jelentőséggel rendelkezik az autógyártás, az elektrotechnika-elektronika, valamint a vegyipar (Szegedi 2007a) - az amerikai termelő vállalatok is ezeken a területeken koncentrálódnak. Emellett Németország a szolgáltatási tevékenységek terén is jelentős szereppel rendelkezik az amerikai vállalatok nemzetközi rendszerében. Franciaország a GDP tekintetében az USA, Japán, Németország és Kína mögött - Nagy-Britanniával együtt - az ötödikhatodik gazdasági nagyhatalom a világon (Szabó 2007, 132). A francia ipar termelési értéke alapján a világ élvonalába tartozik, de a szolgáltatási szektor (a legdinamikusabban fejlődő francia szektor) jelentősége is óriási (Szabó 2007). Az amerikai vállalatok elsősorban a pénzügyi és üzleti szolgáltatások, a gépipar, a jármüipar és a vegyipar területén tevékenykednek Franciaországban.

Svájc is erőteljesen integrálódott mind a világgazdaságba, mind pedig az amerikai vállalati rendszerbe. A svájci exportorientált ágazatokban (vegyipar, gépipar, precíziós műszeripar, óragyártás) döntően tőke- és technológia-intenzív termékeket állítanak elő (http://orszaginfo.itdhungary.com). Ezen ágazatokban - az óragyártástól eltekintve - számottevő a külföldi (köztük az amerikai) tőke jelenléte. Az exportorientált iparágak közül újabban a nagy tőkekoncentrációjú és automatizált vegyipar, azon belül is a gyógyszeripar fejlödik a legdinamikusabban (Szegedi 2007b). A gyógyszervegyészet jelentős mértékủ felértékelődése következtében az amerikai gyógyszeripari vállalatok is egyre nagyobb jelentőséget tulajdonítanak Svájcnak (Barefoot-Mataloni Jr. 2007, 72). 
A világgazdaságba és az amerikai vállalatok érdekszférájába erősen integrálódott Írország gazdasági fejlődésének az elmúlt 20 évben az egyik legfontosabb tényezője a külföldi tőke volt. Az IDA ${ }^{1}$ (,Investment and Development Agency”) tudatos állami befektetés-ösztönzési politikájának eredményeként a nyolcvanas évek közepétől napjainkig a külföldi vállalatok mintegy 160 milliárd eurónyi tőkét invesztáltak írországi termelőegységek létesítésébe (http://www.idaireland.com). A befektetők a tőkével együtt magukkal hozták a korszerü termékeket, gyártási technológiákat és a felvevőpiacokat is. Az ír gazdaság egyik legfontosabb exportágazata az elektronika, ami a kivitelhez 30\%-kal járul hozzá. Az utóbbi években még az elektronikánál is dinamikusabban fejlödik a vegyipar (pl. a gyógyszergyártás), amely a kivitelnek immár 43\%-át adja. Emellett egyre bővül az irodai szolgáltatások köre is (Probáld 2007b, 117). Írország húzóágazataiban ma már meghatározó szerepet játszanak a TNC-k, főleg az amerikai vállalatok. Az általuk előállított termékek nagyobb részt exportra kerülnek (http://orszaginfo.itdhungary.com).

Az elmúlt években a nyugat-európai átrendeződési folyamat azzal a következménnyel járt, hogy csökkent a leányvállalatok földrajzi koncentrációjának mértéke: a 17 nyugat-európai országra számított HHI értéke az 1983 és 2007 közötti időszakban 0,24-röl 0,17-re mérséklödött (ez viszonylag folyamatos csökkenés mellett következett be) (3. ábra).

Közép-, Kelet-és Délkelet-Európában a befektetések igazi lendületet a nyolcvanas és kilencvenes évek fordulóján vettek, amikor is a korábbiakhoz képest jelentős mennyiségü tőke érkezett a régióba (ennek ellenére még mindig alacsony a térség összkibocsátásból való részesedése). Ehhez kedvező feltételeket teremtett a térség államaiban lezajló rendszerváltás, a politikai és gazdasági átalakulás, a meginduló privatizációs folyamat. A befektetések eleinte főleg a privatizációhoz kapcsolódtak, de emellett fontos vonzerőként említhető a térség piaca (Simai-Gál 2000), az olcsó munkaerő és az európai centrumtérséghez való közelség is. Az amerikai TNC-k kezdetben nyugat-európai tevékenységüket terjesztették ki Európa keleti felére, de később az Egyesült Államokból közvetlenül is érkeztek befektetők (Csiki 2004). A térségben a befektetések bővülését 1990 után mindvégig magas értékek jellemezték. Ennek részben az az oka, hogy korábban Európa ezen részében összességében alacsony volt a külföldi - így az amerikai - töke részaránya, másrészt - mivel a térségben a privatizáció folyamata különböző időszakaszokban ment végbe - a befektetések dinamikája végig fennmaradt. Mindemellett idővel már nem csak a privatizációhoz kötődő befektetéseket valósítottak meg a vállalatok, de megjelentek a zöldmezős beruházások, majd a már magánkézben lévő vállalatok felvásárlásai és a vállalati fúziók is. E folyamatok különösen a rendszerváltás (és privatizáció) tekintetében élen járó államokban (Magyarország, Lengyelország, Cseh Köztársaság) nyertek nagyobb teret, emiatt a közép-, kelet- és délkelet-európai befektetések igen magas területi koncentrációt mutatnak: 2007-ben az eladások 48\%-át az említett három közép-európai országban létesített leányvállalatok bonyolították le.

A kilencvenes évek elején még egyértelműen Magyarország számított a régió első számú befektetési területének, az évtized végére azonban az ország részesedése 
jelentősen visszaesett. Előbb Lengyelország, majd a Cseh Köztársaság értékelődött fel számottevően (Csiki 2004). Ám, ahogy a privatizációs folyamat, illetve az amerikai müködőtőke-befektetések egyre inkább más közép- és kelet-európai államot is érintettek, úgy csökkent az említett három közép-európai ország régión belüli kibocsátásból való részesedése is (1993-ban még 74\% volt ezen államok összesített részesedése). Egyre inkább növekszik viszont Oroszországnak a részesedése (1993 és 2007 között 6\%-ról 21\%-ra növekedett az országnak a térségben realizált összesített kibocsátásból való részesedése), ahol az amerikai tőke ma még elsősorban a kitermelőiparban koncentrálódik (http://www.ustr.gov). Oroszország mellett újabban Kazahsztán, Azerbajdzsán és Türkmenisztán ${ }^{2}$ növekvő jelentőségét tartjuk szükségesnek megemlíteni. Az említett országokban a kitermelőipar a legfontosabb és legdinamikusabban bővülő ágazat, a külföldi vállalatok legfontosabb céljai között is a szénhidrogén kitermelésével, illetve szállításával kapcsolatos beruházások megvalósítása szerepel.

Az amerikai kontinens államainak összkibocsátásból való részesedése 2002 és 2007 között évi átlagban $24 \%$-ot tett ki. Az amerikai államok részesedése a vizsgált időszakban csökkent, de ez a csökkenés lényegében csak a nyolcvanas évekre volt jellemzö, 1990 óta a térség részesedése 22\% és 26\% között ingadozik. Ugyanakkor az egyes altérségek, illetve országok szintjén vizsgálódva eltérő folyamatok mutathatók ki.

Bár a Kanadában működő amerikai tulajdonú leányvállalatok részesedésére egyértelmüen csökkenő tendencia jellemző, az amerikai vállalatok Európa után még mindig Kanadát kezelik a második legfontosabb termelőterületnek. Ennek hátterében nagyrészt a földrajzi és a kulturális közelség, az ország ásványkincsben - föleg energiahordozókban - való gazdagsága (Probáld 2004), a két ország között fennálló szabadkereskedelmi megállapodás (NAFTA), a képzett munkaerő, valamint az ipar és szolgáltatási szektor fejlettsége áll. Kanada kitermelőiparában, azon belül is a szénhidrogénszektorban, igen nagy súllyal képviselteti magát az amerikai tőke. De nagyon jelentős amerikai jelenlét jellemzi a szűkebb értelemben vett feldolgozóipar legfejlettebb, legkorszerübb ágait is, amelyek nagyrészt az USA monopóliumainak kezében vannak (Probáld 2004). (Kanada nemcsak a világszintủ kibocsátási adatokat tekintve veszített pozíciójából, de a kilencvenes évek eleje óta az összamerikai kibocsátásból való részesedése is csökkent, ami elsősorban a közép-amerikai térség - azon belül is elsősorban Mexikó - felértékelődésével magyarázható.)

Az 1990-es évek folyamán a vállalatközi fúziós és felvásárlási hullám, valamint az olcsó munkaerőre települő feldolgozóipari vállalatok jelentős amerikai tőkét vonzottak a latin-amerikai térségbe. Latin-Amerikán belül Közép-Amerika, azon belül is Mexikó vonzotta leginkább az amerikai befektetőket: a vizsgált időszak folyamán az országnak az amerikai összesített kibocsátásból való részesedése 4\%-ról 15\%-ra növekedett. Ez rávilágít Mexikó szerepének az amerikai gazdasági erőtérben történő felértékelődésére, illetve az észak-amerikai gazdasági térhez történő szorosabb integrálódására. Mexikóban az amerikai vállalatok jelentős része az ún. „maquiladorák” körébe tartozik. Ezek a termelési egységek - miután 1965-ben a mexikói kormányzat az USA-val „kölcsönös előnyökön” alapuló határ menti ipar- 
fejlesztési programot indított el - Mexikóban már a hatvanas évek második felében megjelentek (Jeney 2004, 195). A két ország által megkötött megállapodás lehetöséget teremtett az amerikai vállalatok számára arra, hogy a munkaerö-igényes termelési fázisokat költségmegtakarítási céllal áttelepítsék Mexikóba, ezzel biztosítva a további világpiaci versenyképességet. Az olcsó munkaerő mellett az ország nagy felvevőpiaca is fontos tőkevonzó tényezőként jelenik meg, így az erőforrás-orientált beruházások mellett a piacorientált beruházások is jelentős szerepet kapnak.

Bermuda és a Karib-térség együttes részesedése mind az amerikai, mind pedig a világszintű összesített kibocsátásból csökkent 1998-ig, ám azóta ismét felértékelődni látszik a térség jelentősége. A térség államainak fő vonzerejét leginkább a képzett és angolul beszélő munkaerő, az információs infrastruktúra fejlettsége és nem utolsósorban a kedvező adózási feltételek jelentik. A térségben realizált értékesítési bevételek fele a világ egyik legjelentősebb „offshore” pénzügyi központjaként számon tartott Bermudán jelenik meg. A térségben még számottevően felértékelődtek a szintén „offshore” területként számon tartott, brit fennhatóság alatt álló szigetek (Kajmán-szigetek, Brit Virgin-szigetek, Anguilla) is. A karibi államok az „offshore” pénzügyi funkció mellett jelentőssé váltak még az ún. „offshore back-office” szolgáltatások (pl. adatfeldolgozás, call-centerek müködtetése) területén is.

A dél-amerikai leányvállalatok az amerikai kibocsátásból a legtöbb évben 18-26\% közötti arányban részesedtek. A dél-amerikai értékesítések valamivel több, mint felét mindvégig a brazil leányvállalatok bonyolították le. Brazília legfőbb vonzerejét a nagy belső piac, a MERCOSUR-tagság ${ }^{3}$, az olcsó munkaerő és a nyersanyagellátottság jelenti, tehát ahogy Mexikó esetében, itt is egyaránt fontosak a piacorientált és az erőforrás-orientált beruházások. Az országban az amerikai TNC-k leányvállalatai elsődlegesen a feldolgozóiparban koncentrálódnak, a feldolgozóiparon belül az autógyártás jelentősége emelhető ki. Brazíliának sikerült elérnie, hogy az autógyártásban érdekelt TNC-k megjelenése (pl. Ford, General Motors, Volkswagen) széles brazil beszállítói ipar kifejlődését vonja maga után (Jeney-Probáld 2004). Brazília mellett Argentínában, Venezuelában, Kolumbiában és újabban Chilében rendelkeznek számottevő érdekeltséggel az amerikai vállalatok. Argentína azonban az ország méretéhez (lakosságszámához) és Brazíliához képest is kevés amerikai tőkét fogad. A külföldi vállalatok befektetéseinek relatíve alacsony mértékéhez hozzájárul, hogy a külföldi befektetőknek nyereségük 30\%-át legalább egy évig az országban kell tartaniuk és újra be kell fektetniük (http://orszaginfo.itdhungary.com).

A fenti folyamatok következtében az amerikai vállalatok földrajzi koncentrációja némileg mérséklödött, de a koncentráció szintje továbbra is nagyon magas (3. ábra).

A kibocsátást tekintve az elmúlt két évtized legnagyobb növekedését egyértelmüen Ázsia és a Csendes-óceáni térség érte el: 1983 és 2007 között a térségbe sorolt államok együttes részesedése 14\%-ról 22\%-ra emelkedett. A nyolcvanas évek elejéhez képest mind a fejlett délkelet-ázsiai országok, mind Japán (bár az ország pozíciója 2000 óta folyamatosan mérséklődik), mind Kína és India világgazdasági pozíciója erősödött. Az újonnan iparosodó fejlődő délkelet-ázsiai államok együttes pozíciója lényegében nem változott, de a csoporton belül erösödött Thaiföld jelentösége, míg az indonéz 
és a fülöp-szigeteki leányvállalatok részesedése jelentősen csökkent. Ausztrália és Új-Zéland összkibocsátásból való együttes részesedése szintén mérséklődött.

Az ázsiai térségben továbbra is kiemelkedő jelentőség tulajdonítható Japánnak és a fejlett délkelet-ázsiai államoknak. Japánban azonban a magas termelési költségek miatt ma már inkább csak a valóban magas hozzáadott értéket termelő leányvállalatok lehetnek világszinten is versenyképesek. Míg Japán részesedését a vizsgált időszak második felében csökkenő tendencia jellemezte, addig a délkelet-ázsiai fejlett államok részaránya folyamatosan növekedett. Ez utóbbi csoporton belül Szingapúr rendelkezik a legnagyobb jelentőséggel, a szingapúri kibocsátásnak az ázsiai összkibocsátáshoz való részesedése a vizsgált időszak folyamán több mint kétszeresére emelkedett. Szingapúr esetében a külföldi vállalatok számára a legfőbb vonzerőt az előnyös földrajzi fekvés, a liberális gazdaságpolitika, a kedvező adózási és pénzügyi feltételek, valamint a magasan kvalifikált és angolul értő munkaerő jelenti. Ezen előnyök hasznosítása érdekében több száz transznacionális vállalat rendelkezik itt képviselettel vagy leányvállalattal (Bernek-Szabó 2008). A térségben jelentős mértékü növekedéssel jellemezhetö még Tajvan és Dél-Korea is. Az erős állami gazdaságpolitika Tajvan és Dél-Korea esetében is fontos szerepet játszott a tőkevonzó-képesség javításában. Ma már mindkét ország a tőke- és technológiaintenzív termékek gyártása terén jelentős. Ez természetesen megkövetelte az oktatás, a képzés, a kutatás-fejlesztés és az innováció felfuttatását. Tajvan esetében mindezeken túl a pénzügyi és üzleti funkció is nagyon fontos (Artner 2002). Bár az 1997-től ismét Kínához tartozó, de különleges igazgatási körzetnek minősülő Hongkongnak az ázsiai eladásokból való részesedése jelentősen nem változott, továbbra is fontos szerepet játszik a térség pénzügyi és kereskedelmi folyamataiban.

A feltörekvő délkelet-ázsiai államok mindvégig 2-3\% közötti részesedéssel rendelkeztek. Ugyanakkor a vizsgált időszak alatt változott a térségbe sorolt államok egymáshoz viszonyított pozíciója. A nyolcvanas évek első felében még Indonézia (elsősorban kőolajszektora) jelentette a délkelet-ázsiai térség legfontosabb termelöterületét, azonban 1992 óta már Malajziát illeti ez a cím. A jelenleg a térségbeli kibocsátás közel 40\%-át lebonyolító Malajzia tudatos és hatékony exportorientált fejlesztési politikájának köszönheti sikerességét. Kezdetben a külföldi befektetők az olcsó, közepesen képzett, angolul értő munkaerőbázisra és a megfelelő szintü infrastruktúrára települve egyszerübb munkaintenzív összeszerelö-tevékenységeket telepítettek az országba. Ahogy a bérek nőttek és modernizálódott a gazdaság, a kormányzat nagyobb hangsúlyt fektetett a képzésre és a technológia fejlesztésére. Az elektronikai TNC-k válaszként automatizált összeszerelö üzemekkel váltották fel a korábban munkaintenzív termelési rendszereket, és magasabb technológiai szintü termékek gyártására helyeződött át a hangsúly. A leginkább munkaintenzív termelési folyamatokat pedig a szomszédos, még ma is alacsony munkabérekkel jellemezhető Vietnámba telepítették át (UNCTAD 1999, 248).

Kina, India és az egyéb ázsiai országok együttes részesedését is növekvő tendencia jellemzi. A csoport tagjai közül Kína játszik kiemelten fontos, és egyre fontosabb szerepet, amit az is jelez, hogy 2002 és 2007 között évi átlagban már az ázsiai 
eladások tizede bonyolódott a kínai leányvállalatok révén. Kínában a külföldi befektetéseket az 1979-es gazdasági nyitás tette lehetővé, de az országba áramló külföldi tőke csak az 1990-es évek elején kezdett jelentősen növekedni. A befektetési környezetet érintő további liberalizációs és deregulációs intézkedések, valamint a gazdasági növekedés, a piac mérete, az állami kedvezmények és a világszinten is olcsó munkaerő jelentősen növelte a külföldi TNC-k befektetési kedvét. Mindezek mellett az országban újabban egyre több figyelmet fordítanak a tudományos képzésre is (Barefoot-Mataloni Jr. 2007, 78). Mindezeknek köszönhetően Kína immár a külföldi tőkebefektetések elsődleges célországává vált. A munkaintenzív termelés mellett egyre magasabb technológiai szintű termékeket is előállít (a high-tech export már 2002-ben az ipari kivitel 22\%-át adta [UNCTAD 2002, 161]); az amerikai vállalatok itteni K+F kiadásai is gyorsan növekednek (Barefoot-Mataloni Jr. 2007, 78).

India pozíciója a kilencvenes években kezdett erősödni, összefüggésben a gazdaság nyitottabbá tételét elősegítő intézkedések sorozatával. Ennek ellenére az ország a térségben lebonyolított eladásokhoz még mindig csak 3\%-kal járul hozzá. Véleményünk szerint ebben szerepet játszik az is, hogy a Kínához képest demokratikusabb és decentralizáltabb Indiában hiányzik az a fajta erős, központi kormányzati politika, ami Kína sikerességében oly nagy szerepet játszik. A feldolgozóipari befektetések növekedését akadályozza még a müszaki infrastruktúra elmaradottsága is. India fö vonzerejét elsősorban a nagy belső piac és az angolul értő képzett (különösen az IT és a müszaki területeken) munkaerő jelenti. A gazdasági fellendülés egyik húzóerejét az IT jelenti (Szegedi-Wilhelm 2008), az országba érkező amerikai befektetések is elsősorban az információs technológiákra épülő szolgáltatások területein koncentrálódnak.

A fenti folyamatok következtében (hangsúlyozva Kína és India felértékelődését) a nyolcvanas évek végétől a HHI alapján mért területi koncentráció az ázsiai térségben is jelentősen mérséklődött (3. ábra).

Az amerikai vállalatok marginális jelentőséget tulajdonítanak Afrikának és a KözelKeletnek. Az afrikai és közel-keleti országokba irányuló befektetések nagyrészt a természeti erőforrásokat kiaknázó kitermelőiparban és az olajágazatban koncentrálódnak (ez leginkább Afrikára jellemző). Ám mivel a primer szektor relatív súlya az amerikai befektetések terén összességében csökkent, így e térségek relatív súlya is mérséklödött. S bár az ezredfordulót követö időszakban a kőolajárak növekedésének köszönhetően ismét növekedett a szektor súlya, ez csak kismértékü emelkedést eredményezett az afrikai és a közel-keleti leányvállalatok összkibocsátásból való részesedésében. Mind Afrikában, mind a Közel-Keleten erős területi koncentráció jellemző, bár ennek mértéke a vizsgált időszakban mérséklődött. Afrikában az amerikai befektetők nagyobb jelentőséget csupán Nigériának, a Dél-afrikai Köztársaságnak és Egyiptomnak szántak (eladásokból való együttes részesedésük 2002-2007 között évi átlagban $44 \%$ volt). Nigériában és Egyiptomban túlnyomórészt a kitermelőiparban koncentrálódnak az amerikai vállalatok, a Dél-afrikai Köztársaságban ennél kiegyenlítettebb az amerikai vállalatok ágazati megoszlása. Az említett három ország mellett még a kőolajjal rendelkező országokba áramlik nagyobb mennyiségü ameri- 
kai tőke (vállalati kutatások is igazolják ezt, pl. nőnek az ExxonMobil befektetései az egyéb afrikai országokban is: Angola, Egyenlítői-Guinea, Kamerun, Csád [www.exonmobil.com])

A Közel-Keleten a legfontosabb kibocsátóként Törökország, Szaúd-Arábia, az Egyesült Arab Emírségek és Izrael tartható számon, e négy államban létesült leányvállalatok bonyolítják le a közel-keleti leányvállalatok értékesítésének négyötödét. Izrael esetében a magas technológiai fejlettséget képviselö, jelentős $\mathrm{K}+\mathrm{F}$ igényü feldolgozóipar és a szakértelmet igénylő szolgáltatások adják a kibocsátás jelentős hányadát. Az izraeli gazdaság motorjának ma már az innovatív, magas hozzáadott értéket előállító ágazatok (high-tech szektor, a generikus gyógyszergyártás, információs szolgáltatások) tekinthetők. 2008-ban a high-tech szektor a teljes ipari kivitel 52\%-át adta (a gyémántkivitel nélkül). A K+F-kiadások GDP-hez viszonyított aránya $(4,8 \%)$, valamint a PhD-fokozattal rendelkezők, a tudományos publikációk, a mérnökök és tudósok lakosságon belüli aránya a világon az egyik legmagasabb (http://orszaginfo.itdhungary.com).

Szaúd-Arábiában és az Egyesült Arab Emírségekben a leányvállalatok kibocsátásának igen tekintélyes részét a nagykereskedelmi leányvállalatok bonyolítják le, azaz a két ország disztribúciós szerepe vált jelentőssé. A másik fontos vonzerőt a kőolaj jelenti. Az Egyesült Arab Emírségek növekvő müködőtőke-importja a gyorsan fejlödő és világviszonylatban is versenyképes szabadkereskedelmi övezetek hálózatának is köszönhető. A kedvező viszonyok következtében a TNC-k többsége ide - föként Dubaiba - telepíti regionális központját, disztribúciós vagy logisztikai irányító részlegét (http://orszaginfo.itdhungary.com).

Törökország szerepének növekedése az amerikai-török kapcsolatok felértékelödését is jelzi. A két ország vezetői számos megállapodást kötöttek az elmúlt években, beleértve a kereskedelmi és befektetési egyezményeket is. Törökországban az amerikai befektetések elsődlegesen a pénzügyi szektorban és a feldolgozóiparban koncentrálódnak (http://www.ustr.gov).

\section{Konklúzió}

A kutatás középpontjában az amerikai TNC-k hálózatának kibocsátási (értékesítési) adatokra alapozott vizsgálata állt. A vizsgálatok során választ kerestünk arra a kérdésre, hogy milyen tendenciák jellemzőek az amerikai vállalatok nemzetköziesedettségére, s hogy ezzel együtt miként változott a vállalatok térszerveződése.

A kutatás eredményeit az alábbi 3 pontban foglaljuk össze:

1) A tanulmányban elsőként arra a kérdésre kerestük a választ, hogy a vizsgált időszak folyamán változott-e az amerikai vállalatok nemzetköziesedettsége. Az empirikus vizsgálatok azt mutatják, hogy az amerikai TNC-k nemeztköziesedettsége 1983 és 2007 között fokozódott, azaz napjainkban az amerikai vállalatokra valóban erőteljesebb aktivitás jellemző a külpiacokon, mint a nyolcvanas években. 
2) A második kérdésünk arra vonatkozott, hogy az amerikai vállalatok földrajzilag kevésbé differenciáltan szerveződnek-e napjainkban, mint a korábbi időszakokban. A vizsgálatok azt mutatják, hogy a nyolcvanas években, amikor is a befektetések elsősorban a fejlett államokat célozták meg, még erősödött a területi koncentráció. Ugyanakkor a nyolcvanas évek vége, a kilencvenes évek eleje óta már kiegyenlítettebbé vált az amerikai vállalatok térbeli megoszlása. Ez leginkább az ún. feltörekvő piacok (pl. Malajzia, Mexikó, Kína; India; Közép-, Kelet- és Délkelet-Európa) felértékelödésének volt köszönhetö.

3) A harmadik kutatási kérdésünk arra vonatkozott, hogy az egyes nagytérségek és államok jelentősége érdemben változott-e. Az amerikai TNC-k térszerveződésének vizsgálatát értékelve elmondható ugyan, hogy az egyes országok és térségek részesedését tekintve történtek változások, de ezek összességében nem voltak olyan mértéküek, hogy azok az amerikai vállalatok nagymértékü területi átrendeződésével jártak volna. A korábbi fő kibocsátási területek közül a fejlett délkelet-ázsiai államok (Szingapúr, Hongkong, Tajvan, Dél-Korea) és a közép-amerikai országok (elsősorban Mexikó és Costa Rica) értékelődtek fel. Emellett számottevő növekedéssel jellemezhető még néhány kisebb méretü európai állam (Írország, Luxemburg) is. A hagyományos befektetési területek mellett új termelőterületek is feltüntek, ezek közül elsősorban Közép-, Kelet- és Délkelet-Európa, Kína és India tőkevonzó képessége javult a legnagyobb mértékben. Kína és India felértékelödése a kilencvenes évektől mutatható ki, a világ két legnépesebb országában a piac és az erőforrásorientált beruházások egyaránt jelentőssé váltak. A politikai és gazdasági átalakulási folyamat hatására a közép-, kelet- és délkelet-európai térségben is egyre több amerikai transznacionális vállalat kezdte meg működését a kilencvenes évek elejétől. A térségben az amerikai vállalati befektetések kezdetben a rendszerváltás tekintetében élen járó közép-európai államok (Cseh Köztársaság, Magyarország, Lengyelország) felé irányultak. Ám, ahogy az átalakulási folyamatok más térségbeli államot is érintettek, úgy bővült az amerikai érdekszférába bekerülő országok köre is. A legutóbbi években a térségbeli vállalatok kibocsátásából egyre nagyobb arányban részesednek a szovjet utódállamok, elsősorban Oroszország és a középázsiai térség. A kitermelőipar utóbbi években tapasztalt újbóli felfutása miatt Afrika és a Közel-Kelet kismértékü részesedésnövekedésére is számítani lehetett, de ez csak minimális mértékben következett be, e két térség összességében továbbra is minimális érdeklődést vált ki az amerikai befektetőkből. A vizsgált időszak folyamán jelentősen nem változott Japán és Dél-Amerika részesedése sem, e két gazdasági térség végig 5-5\% körüli részaránnyal rendelkezett. Bermuda és a Karib-térség részesedése viszont a kilencvenes évek második feléig még csökkent, ám azóta kismértékü növekedés mutatható ki. Mindeközben néhány nagy világgazdasági súllyal rendelkező állam - pl. Kanada, Franciaország, Németország - pozíciója gyengült, ugyanakkor Európa részesedése összességében jelentősen nem esett vissza, azaz az amerikai TNC-k külföldi leányvállalatainak térszerveződésére továbbra is erőteljes európai orientáció jellemző. 
Annak ellenére, hogy napjainkban az amerikai vállalatok térben szórtabban szerveződnek, mint a nyolcvanas években, még mindig magas földrajzi koncentráció mérhető: 2007-ben az 5 legfőbb célország eladásból való részesedése $41 \%$, a 10 legmagasabb részesedésü állam részesedése $62 \%$ volt. Az erős területi koncentráció valamennyi nagytérségi szinten kimutatható, de különösen magas koncentráció jellemző a Közel-Keletre, Afrikára és Közép-, Kelet- és Délkelet-Európára. Afrikában az amerikai vállalatok nagyobb jelentőséget csupán Nigériának, a Délafrikai Köztársaságnak és Egyiptomnak szántak; a Közel-Keleten a legfontosabb kibocsátási területként Törökország, Szaúd-Arábia, az Egyesült Arab Emírségek és Izrael tartható számon. Közép-, Kelet- és Délkelet-Európában a cseh, a lengyel és magyar leányvállalatok bonyolítják le az értékesítések felét.

\section{Jegyzetek}

${ }^{1}$ Írországban az IDA Ireland (The Industrial Development Agency of Ireland) adhat ösztönző céllal támogatást a beruházásokhoz. Az IDA fö feladata a külföldi befektetők és befektetések Írország számára való megnyerése. Kezdetben a munkahelyteremtés, napjainkban pedig a K+F tevékenységek és a tudásbázisú gazdaság kiépítése a stratégiai cél (www.idaireland.com).

${ }^{2}$ Ezen államokat a BEA statisztikailag Európához sorolja, bár valójában közép-ázsiai államokról van szó.

${ }^{3}$ A MERCOSUR lehetőséget teremt a többi tagország piacának Brazílián keresztül történő kiszolgálására.

\section{Irodalom}

Artner A. (2002) Híradás a fejlődő országokról. Délkelet-Ázsia: Válság után, alatt, előtt? - Magyar Tudomány. 7. 856-862. o.

Barefoot, K.B.-Mataloni Jr., R.J. (2007) U.S. Multinational Companies. Operations in the United States and Abroad in 2007. Survey of Current Business (SCB).

Bernek Á. (2002) A transznacionális vállalatok világgazdasági jelentősége. - Bernek Á. (szerk.) A globális világpolitikai földrajza. Nemzeti Tankönyvkiadó, Budapest. 162-181. o.

Bernek Á.-Szabó P. (2008) Az Indokínai félsziget országai. - Horváth G.-Probáld F.-Szabó P. (2004) Ázsia regionális földrajza. ELTE Eötvös Kiadó, Budapest. $564-589$. o.

Csiki A. (2004) Az amerikai transznacionális vállalatok térszerveződése az 1990-es években. - Tér és Társadalom. 3. 91-110. o.

Dicken, P. (2003) Global Shift: Reshaping the Global Economic Map in the 21st Century. 4 th edition. Sage Publications Ltd., London.

Jeney L. (2004) Mexikó. - Probáld F. (szerk.) Amerika regionális földrajza. Trefort Kiadó, Budapest. 179-201. o.

Jeney L.-Probáld F. (2004) Brazília. - Probáld F. (szerk.) Amerika regionális földrajza. Trefort Kiadó, Budapest. 313-336. o.

Nemes Nagy J. (1998) A tér a társadalomkutatásban. Hilscher Rezső Szociálpolitikai Egyesület, Budapest.

Probáld F. (2004) Kanada. - Probáld F. (szerk.) Amerika regionális földrajza. Trefort Kiadó, Budapest. 138-167. o.

Probáld F. (2007a) A Benelux-államok. - Probáld F.-Szabó P. (szerk.) Európa regionális földrajza. Társadalomföldrajz. ELTE Eötvös Kiadó, Budapest. 53-79. o.

Probáld F. (2007b) Írország. - Probáld F.-Szabó P. (szerk.) Európa regionális földrajza. Társadalomföldrajz. ELTE Eötvös Kiadó, Budapest. 112-119. o.

Simai M.-Gál P. (2000) Új trendek és stratégiák a világgazdaságban. Vállalatok, államok, nemzetközi szervezetek. Akadémiai Kiadó, Budapest. 
Szabó P. (2007) Franciaország. - Probáld F.-Szabó P. (szerk.) Európa regionális földrajza. Társadalomföldrajz. ELTE Eötvös Kiadó, Budapest. 119-149. o.

Szegedi N. (2007a) Németország. - Probáld F.-Szabó P. (szerk.) Európa regionális földrajza. Társadalomföldrajz. ELTE Eötvös Kiadó, Budapest. 151-192. o.

Szegedi N. (2007b) Svájc. - Probáld F.-Szabó P. (szerk.) Európa regionális földrajza. Társadalomföldrajz. ELTE Eötvös Kiadó, Budapest. 192-208. o.

Szegedi N.-Wilhelm Z. (2008) India. - Horváth G.-Probáld F.-Szabó P. (szerk.) Ázsia regionális földrajza. ELTE Eötvös Kiadó, Budapest. 404-440. o.

UNCTAD (1995) World Investment Report 1995: Transnational Corporations and Competitiveness. New York, Geneva.

UNCTAD (1999) World Investment Report 1999: Foreign Direct Investment and the Challenge of Development. New York, Geneva.

UNCTAD (2002) World Investment Report. Transnational Corporation and Export Competitivness. New York, Geneva.

http://orszaginfo.itdhungary.com

http://www.bea.gov

http://www.exonmobil.com

http://www.idaireland.com

http://www.ustr.gov 